\title{
Teaching and Learning Sustainability during and beyond COVID-19: A Review of Business and Management Studies
}

\author{
Sashika Abeydeera \\ Senior Lecturer, Department of Management and Organization Studies, \\ University of Colombo
}

\section{ABSTRACT}

This review article explores how teaching and learning approaches to sustainability in higher education need to be transformed to suit the Business and Management Studies context in Sri Lanka. This is imperative in light of the unprecedented demands of the COVID-19 pandemic. Despite a recent proliferation of programs on sustainability in higher education, current teaching and learning approaches do not adequately address the scale of sustainability issues, especially during and beyond the pandemic. The article draws on a semi-systematic literature review on teaching and learning sustainability in Business and Management Studies. It highlights five broad themes that emerged: (1) the necessity for a broader understanding of sustainability, (2) sustainability in the Sri Lankan context, (3) current teaching and learning approaches to sustainability, (4) the need for a transformation, and (5) challenges posed by the pandemic. It argues that a critical skill set amongst students incorporating reflexivity, critique, problemsolving, and social action/engagement, and an attitudinal change that incorporates a holistic/integrated and multi-level approach to teaching and learning sustainability are prerequisites.
\end{abstract}

\section{KEY WORDS:}

Sustainability, teaching and learning, higher education, business and management, COVID-19, Sri Lanka

Suggested Citation: Abeydeera, S. (2021). Teaching and learning sustainability during and beyond COVID-19: A review of business and management studies. University of Colombo Review (New Series III), 2(1), 138 - 154.

(C) 2021 The Authors. This work is licenced under a Creative Commons Attribution 4.0 International Licence which permits unrestricted use, distribution, and reproduction in any medium, provided the original work is properly cited. 


\section{Introduction}

Sustainability has become a frequently emphasized term by policymakers, and business and national leaders, especially during the COVID-19 pandemic. What is sustainability and why has it gained traction during these unparalleled times? From a broad perspective, sustainability is "the capacity to endure" (Fogarty et al., 2013, p. 2482). This definition connotes resilience in building adaptive capabilities in a world of transformations. The unprecedented disruption brought about by the pandemic constitutes, therefore, an opportunity and a turning point for both international and local leaders and administrators alike, to rethink and reorient their actions towards enhancing the capacity to endure - i.e., sustainability.

The country's business sector bears a significant responsibility in revamping the economy, creating entrepreneurial possibilities and job opportunities which will sustainably revive the national economy after the pandemic. However, a recent global survey which indicates that businesses and industries need to be more involved in economic revival (Globescan, 2020), is equally applicable to Sri Lanka.

The pandemic's significant blow to the country's socio-economic fabric also calls for urgent action on the part of educators involved in higher education institutes (HEIs). Teachers/facilitators in Business and Management Studies have a pivotal role to play in nurturing leadership and managerial capabilities of students who will become future leaders/decision-makers. Students need to be taught what sustainability is, and how they can develop businesses towards a sustainable economic revival. In this context, what should be the role of educators? This literature review on teaching and learning approaches to sustainability in higher education provides some answers.

\section{Teaching and Learning Sustainability}

HEIs possess the potential to make a significant contribution to sustainability through research, education, thought leadership and civic engagement, and many have already done so for several years (Higher Education for Sustainable Development, 2015). Higher education programs on sustainability in business management have proliferated in the recent past (Brunnquell \& Brunstein, 2018; Collins \& Kearins, 2007; Kearins \& Springett, 2003; O'Byrne et al., 2015). Yet, analysis shows that such programs, embedded in the current education system, do not sufficiently address the scale of the issues relating to sustainability (Banerjee, 2011; Brunnquell \& Brunstein, 2018; Jones et al., 2010). A pre-eminent thought leader in sustainability, John R. Ehrenfeld, states that "many companies have a CSO, Chief 'sustainability' Officer, and many more business schools offer 'sustainability' minors... [yet] these developments have not changed much: profit still rules the roost, and trends in technology are themselves contributing to the commoditization of people" $(2019$, p. 2$)$.

With the COVID-19 outbreak, higher education is at the cusp of a radical transformation. Instigating such a change among learners and educators calls for embedding properly designed course options/programs on sustainability into the curricula and learning how to teach them. New ways of teaching and learning sustainability are required. For example, it is suggested that inter-and trans-disciplinary (Brundiers \& Wiek, 2013; Martens 
et al., 2010), and participatory approaches be adopted as pedagogies when engaging with the local context and community needs (Brundiers et al., 2010; Yarime et al., 2012). Despite the implications of such pedagogies for multiple disciplines including natural sciences, arts, and humanities etc., the purpose of this article is to take a closer look at how sustainability needs to be re-learned and taught within Business and Management Studies in higher education contexts in Sri Lanka.

Following a discussion on methodology, this review article highlights insights gained through an analysis of the relevant literature. Implications for academics/educators, academics-cum-administrators, and undergraduate and postgraduate students are discussed thereafter. The article concludes with directions for future inquiry.

\section{Methodology}

This article is based on a semi-systematic literature review which aimed at gauging how sustainability is understood and taught in Business and Management Studies in higher education contexts. A semi-systematic process, as against a full systematic review, was found to be a more appropriate methodology as it explores complex concepts which are "conceptualized differently" (Snyder, 2019, p. 334). A semi-systematic review also facilitates the identification of themes that arise in the literature over a period of time as well as the knowledge gaps (Snyder, 2019).

An initial search of the literature, including journal articles, edited volumes and book chapters was carried out using the keywords "sustainability", "teaching and learning", "higher education", "business and management", "COVID-19", and "Sri Lanka". Extant literature pertaining to disciplines other than business and management studies (e.g., medical/scientific studies and those related to the pandemic) were excluded. The review comprised 40 journal articles, 14 books, and 4 edited book chapters, adding up to a total of 58 sources. The relevant literature was screened by reading the abstracts and given keywords. In addition to this search, references provided in the selected literature pertaining to the Sri Lankan context, and the pandemic and its impact on teaching and learning methodologies in higher education were explored. The patterns that emerged during the analysis of this literature are presented thematically under five broad areas: (1) sustainability as a concept, (2) sustainability in the Sri Lankan context, (3) current teaching and learning approaches to sustainability, (4) the need for transformation, and (5) changes posed by the pandemic. A discussion of these themes will be presented next.

\section{What is Sustainability?}

Interpretations of sustainability vary "from business-as-usual short-term economics to new long-term deeply ecological and restorative business models" (Schein, 2015, p. 148). Due to the diversity of its meanings, sustainability is recognized as a complex and poorly-defined concept in the Management and Organizational Studies literature (Banerjee \& Bonnefous, 2011; Ehrenfeld, 2008, 2012; Gladwin et al., 1995; Harris \& Tregidga, 2012; Milne et al., 2006; Schein, 2015). In this context, “it is higher education's responsibility to continuously challenge and critique value and knowledge claims that have prescriptive 
tendencies" (Wals \& Jickling, 2002, p. 221). Prescriptive tendencies are narrow and rigid approaches to teaching sustainability through outdated theories and models, rather than enabling learners to actively engage in dialogue and debate towards exploring the meaning of sustainability.

Traditionally, Management and Organization Studies have underscored the prime objective of a business entity to be the wealth maximization of its shareholders/owners (Banerjee, 2003; Daniels, 2011, 2014; Molthan-Hill, 2015). The emphasis here is on self-centeredness rather than empathy, control over resources rather than cooperation and redistribution, and materialistic possession rather than social harmony (Daniels, 2011). These values fail to recognize the mutual interconnectedness of business leaders/ decision-makers and greater society including the need to safeguard nature (Daniels, 1998, 2007, 2011; Ehrenfeld, 2008, 2012; Laszlo et al., 2014). Leaders need to understand that businesses do not operate in a vacuum. They rely on both communities and nature for sourcing inputs and offering outputs including products, services, and disposal of waste. Thus, business leaders have a social responsibility towards larger society and nature, and to the link between themselves and a web of connections.

During challenging times such as the pandemic and beyond, students should be taught to see connections between themselves and the larger society. How sustainability is interpreted plays a crucial role in such an attitudinal shift. Ehrenfeld and Hoffman (2013) posit sustainability as "the possibility that human and other life will flourish on the Earth forever" (p. 7), and argue that it hinges on the long term interconnectedness of humans with all other beings in society and nature.

The literature reviewed also indicates a continuum from weak to strong sustainability based on the level of integration of the three common dimensions - economic, social, and environmental (Harris \& Tregidga, 2012; Roome, 2012; Springett, 2003). Weak sustainability permits trade-offs among the three dimensions (e.g., accommodating economic motives at the expense of preserving natural habitats) whereas, strong sustainability does not allow trade-offs, thereby accentuating the close integration of all dimensions (Hahn et al., 2010).

Understanding the context of the debate on sustainability (contextualization) is also vital if educators and students are to select the proper teaching and learning approaches to the topic within Business and Management Studies in higher education. The section that follows looks at how sustainability is interpreted within the Sri Lankan context.

\section{Sustainability in the Sri Lankan Context}

Sustainability in the local context is often interpreted as corporate social responsibility (CSR) which mainly connotes charity, giving back to society, community outreach, and/ or philanthropic endeavors (Abeydeera et al., 2016). A possible reason for this approach is the strong inclination of Sri Lankans for philanthropy as part of their cultural identity (Nanayakkara, 1992, 1997) and strong religious outlook (Gombrich \& Obeyesekere, 1988).

The normative influence of religion in general, and of Buddhism in particular, has had a profound impact in determining the rationale for businesses to engage in CSR initiatives (Fernando \& Almeida, 2012; Fernando \& Jackson, 2006; Fernando et al., 
2015; Karunatilake, 2004; Kumarasinghe \& Hoshino, 2010). However, this philanthropic orientation in the Sri Lankan business and local industry context has influenced its leaders and decision-makers to take a narrower, more superficial view of sustainability (Abeydeera et al., 2016). Transformations do not occur when sustainability is viewed as a mere philanthropic activity which undermines its overarching strategic and systemic focus and potential. Thus, it is imperative for educators, in particular, to develop a more profound and holistic understanding of sustainability as a systems-level concept and not as a mere one-off charity. One needs, therefore, to juxtapose the core business strategy or purpose of an enterprise, against its collective responsibility within the web of connections it operates in, which includes employees, customers, suppliers, the greater community and nature etc.

Such a broad understanding of sustainability, as evident in the reviewed literature published both globally and locally, will open up new opportunities for educators involved in higher education to explore better ways of teaching and learning sustainability. However, before exploring more effective avenues to teaching and learning sustainability, we need to take stock of how sustainability is currently taught and learned in Business and Management Studies at tertiary level.

\section{Current Teaching and Learning Approaches to Sustainability}

Researchers engaged in teaching and learning sustainability in the field of business and management postulate that extant approaches are inadequate to meet the challenges posed by sustainability (Brunnquell \& Brunstein, 2018; Collins \& Kearins, 2007; Kearins \& Springett, 2003; Springett, 2003). They call, therefore, for an overall conceptual change in sustainability education. As Brunnquell and Brunstein (2018) state, "a purely pragmatic and technical conception in the teaching and learning of sustainability does not sufficiently contribute to the development of professional managers with strong sustainability principles and standards" (p. 25). Sustainability relies on a multiplicity of foundational disciplines (e.g., geography, environmental science, ecology, economics, political science, and sociology) that span across various academic disciplines (Clark, 2007; Wals \& Jickling, 2002). Yet, sustainability is conceptualized by educators in relation to the nature of the problems it tackles, rather than the disciplines it connects with (O'Byrne et al., 2015).

Issues of sustainability identified within a business context can be categorized into three dimensions - economic, social, and environmental - which is commonly referred to as the triple bottom line (TBL). Brunnquell and Brunstein (2018) state that the most common teaching and learning approach revolves around the TBL. TBL, as defined by John Elkington (1997), refers to a business's capability in creating economic, social, and environmental gains while simultaneously contributing to sustainable development. TBL's validity "[w] $[\mathrm{w}$ ould become more apparent if companies did not limit their understanding to a utilitarian and functionalist logic, which ends up weakening the potential of the triple bottom line" (Brunnquell \& Brunstein, 2018, p. 27). Such narrow logic shrinks the potential and scope for transformative changes in teaching and learning sustainability as well.

Current pedagogies on sustainability are also limited by their emphasis on a single entity rather than a systemic focus (Collins \& Kearins, 2007; Ehrenfeld, 2019). An entity 
focus entails sustaining the business itself, but not the whole supply chain in which it is embedded. It is a narrow focus which overlooks the web of connections the company possesses which includes its employees, customers, suppliers, nature etc., all of whom/ which are stakeholders. On the contrary, a systemic focus emphasizes the value of this interconnectedness, stakeholder engagement of a business and its role in wider society (e.g., from an issue-based rather than a purely firm-centric approach) (Collins \& Kearins, 2007).

Mainstream discussions of sustainability in Business and Management Studies tend to primarily focus on profit and growth motives (Banerjee, 2012; Banerjee \& Bonnefous, 2011; Ehrenfeld, 2008). As Banerjee states, "[a]lmost all of the research on organizational approaches to environmental issues takes a functionalist approach that privileges organizational rather than environmental goals" (Banerjee, 2012, p. 572). When educators of sustainability subscribe to a functionalist approach, they tend to overlook the intricate interconnections among stakeholders - including the natural environment. Such a standardized approach which emphasizes mundane management practices, including costcutting strategies and win-win situations, have been challenged by critical management and organizational scholars (Banerjee, 2012; Ehrenfeld, 2008; Kearins et al., 2010; Springett, 2003). The critique argues that the underlying assumptions of the functionalist approach will only permit an incremental improvement to the status quo, rather than enabling a radical transformation, limiting the learners' capacity to see sustainability from a holistic and long-term perspective.

Wals and Jickling (2002) suggest that tertiary level learners need to actively observe and keep track of the evolving subject matter/content related to sustainability. The authors contend that it is higher education's responsibility to engage students in brainstorming sessions and debates, allowing them to challenge and continuously critique value and knowledge claims that are limited/narrow in scope. In promoting such inquiry, especially in business and management, educators will need to reflect upon the need to transform their teaching approaches to sustainability.

\section{The Need for Transformation}

A transformative shift from the current teaching and learning approach to a more comprehensive and inclusive one requires educators to integrate sustainability into higher education through new pedagogical methods which are experiential and systemic (Bawden $\&$ Wals, 2000). Shifts from teacher-centered to learner-centered, individual to collaborative, low cognitive to higher cognitive, and from mere knowledge accumulation to experiential (creative problem-solving) and lifelong learning are called for. How should pedagogies be changed to include the above, and better prepare students to be sustainable leaders and citizens?

John Biggs, an educational psychologist, claims that the degree of teaching and learning activity and the academic orientation of students jointly affect the latter's levels of engagement (Biggs, 1999). According to Biggs, academically oriented students will adopt deep learning approaches irrespective of how they are taught. Students who are not 
academically oriented are likely to adopt a deep learning approach only under the most conducive of teaching conditions. Biggs further suggests that problem-based learning would be an example of an active method because it requires the average student to question, speculate, generate solutions, and adopt higher-order cognitive skills that more academically oriented students use spontaneously. Thus, it is understood that teaching realworld case studies and practical/ hands-on projects narrows the gap between the average and academically oriented student, thereby encouraging most students to develop and use higher-order cognitive skills. In similar vein, a problem-based approach facilitating active student engagement will be helpful in teaching and learning sustainability in Business and Management Studies.

Student engagement needs to be built into the design of teaching and learning activities rather than expecting it to automatically emerge from them. The purposeful design of interdisciplinary teaching and learning activities will enable students to connect information from different and separate disciplines which, in turn, will enhance their "higherorder cognitive skills such as problem-solving, critical thinking, and the ability to employ multiple perspectives" (Lattuca et al., 2004, p. 23). Although interdisciplinary education is a much-felt need in the business and management context, educators require further training in how to craft interdisciplinary teaching and learning activities (Buttermore, 2011; Fernando et al., 2020; Lindvig \& Ulriksen, 2019; Shay, 2016).

In his theory of experiential learning (ELT), David Kolb, who is a psychologist and educational theorist, explicates a holistic learning process where learning occurs between individual(s) and the environment. Learning is considered "a process rather than an outcome" as well as "a holistic process of adaptation" (Kolb \& Kolb, 2009). Experiential learning needs to be an essential part of education. Kolb and Kolb (2009) discern that learning in management is not achieved by mere cognition (knowledge) alone, but "involves the integrated functioning of the total person - thinking, feeling, perceiving and behaving" (p. 43). Moreover, such learning transcends the individual, to also incorporate team and organizational levels.

Astudy based on Kolb's experiential learning in business and management emphasizes the necessity for creating opportunities for students to develop their inquisitiveness, leading to creativity (Buttermore, 2011). Here, students make observations from multiple perspectives, combining their imagination, experiences, and feelings/emotions. The reflective practice that follows, permits students to relate their own life experiences to their learning (Fernando et al., 2020; O’Connell \& Dyment, 2011).

A sound understanding of one's values and institutional structures is required to foster a sustainable mindset in business education (Clark, 2007; Ehrenfeld, 2019). This calls for allowing learners to question underlying assumptions of self, as well as managerial theories, models, and practices learned which contradict sustainable management, so that better alternatives towards sustainability can be envisaged (Ehrenfeld, 2019). Therefore, critical reflection and transformative learning are crucial for a new paradigm in teaching and learning sustainability. 


\section{COVID-19 and its Challenges}

Unlike other world crises, the COVID-19 pandemic has had a severe impact on economies and communities on a global scale (PricewaterhouseCoopers, 2020) and caused reversals to education (UNESCO, 2020). In the face of its subsequent threats to socioeconomic conditions, governments worldwide have spent vast amount of funds on saving lives and communities (PricewaterhouseCoopers, 2020). Public health is a priority: but has education been given its due share of attention? An appropriate and effective education will assist economies in turning the pandemic into a catalyst, translating threats into opportunities, and facilitating a sustainable economic recovery (UNESCO, 2020).

As educators with broad concerns about health, climatic and socio-economic conditions, more diversity of thought is necessary. Higher education has the potential to shape human adaptation through exploration, reflexivity, critique, creativity and community engagement (Kearins \& Springett, 2003). These will enable students to question their own assumptions and the status quo of businesses in order to introduce more restorative business models (Schein, 2015). Ultimately, they will create opportunities for sustainability rather than simply minimizing unsustainable practices (Ehrenfeld, 2019) which is the more common approach to sustainability today.

The sudden change from a physical/in-person teaching and learning mode to a more remote/online mode because of the pandemic required grit, resilience and self-reliance on the part of students and faculty alike. This was a change faced by all educators, whether at primary, secondary or tertiary level. Instead of considering it a stumbling block, the critical task is to turn it into an opportunity for a more thoughtful, strategic transformation of higher education, while taking the time to rethink and redesign the scope and scale of higher learning. Excellent online learning outcomes happen by design, and therefore, adopting proper pedagogy matters. Well-designed teaching and learning activities also help learners acquire and master new skills that would transform their entire lives (UNESCO, 2020).

This enforced shift from onsite to online opens doors to a virtual century, which would affect our ways of teaching, learning, communicating, transacting and consuming (UNESCO, 2020). Businesses have been compelled to adopt new models, manage complex supply chains, and connect with a largely remote workforce (Cohen et al., 2020). Every business has to now become part of a new health ecosystem. The health concerns amplified during the crisis will not ebb after the pandemic is over. Instead, health and safety will dominate the foreseeable future. These changes will need to be reflected in Business and Management Studies on sustainability.

The issues of sustainability that businesses confront are inherently complex (Ehrenfeld 2008; 2012; 2019). As educators in Business Studies, it is imperative to underscore the demands of a VUCA world, the managerial acronym for "volatility", "uncertainty", "complexity" and "ambiguity" (Bennett \& Lemoine, 2014), in order to demonstrate the nature of real-world problems to students. It is vividly evident that while the COVID-19 pandemic has placed unprecedented demands on business, the industry's response needs to demonstrate its resilience and agility in bringing about innovations to market. Cohen et al. (2020) state that businesses that invest in innovation during a crisis outperform their peers 
in the recovery. In this context, how do we boost students' creativity, which in turn will enable them to innovate?

Where different ways of looking at the world meet, dissonance is created, and learning is likely to occur (Wals \& Jickling, 2002). Socio-scientific debates/disputes help new knowledge and values surface. Participation in such debates/disputes provides an excellent opportunity to learn about the need for transformation (Wals \& Jickling, 2002). If our HEIs do not facilitate such a learning process which is attentive to dissonance, they fail to involve students in one of the biggest challenges of our time. Competencies that will enable students to cope with uncertainty, poorly defined situations, and conflicting, or at least diverging, norms, values, interests and realities even beyond COVID-19, are equally important. Thus, sustainability education must not only be about knowledge imparted by experts/teachers which learners/students thereafter reproduce.

\section{Insights from the Literature Review}

Effective teaching and learning on sustainability help students, as potential future leaders and decision-makers, to make sense of the world in which they live, and the complexity and interconnectedness of its problems. It also helps them develop the new knowledge and skills necessary for a sustainable future (Brunnquell \& Brunstein, 2018; Collins \& Kearins, 2007; Ehrenfeld, 2019; Fernando et al., 2020; O’Byrne et al., 2015). Yet, promoting effective teaching and learning is challenging as it involves dealing with conflicts, tensions, and paradoxes (Brunnquell \& Brunstein, 2018). It requires educators to review and redefine business growth more holistically from a broader societal perspective, and disseminate such an understanding to students. Growth needs to be interpreted as enabling and enhancing the wellbeing of all stakeholders with whom the business interconnects. This goes against the current priorities of business strategy. It is imperative, however, for Business and Management Studies educators to boost learners' intellectual capacity to be more hands-on and proactive about creating a common wellbeing for all society, rather than concentrating on remedies to merely reduce the pandemic's negative impact on society (Ehrenfeld, 2019).

With the dire financial situation brought about by the pandemic and with few options for accessing concessional financing, Sri Lanka's national economy will require diversification, even moving away from industries and businesses such as tourism which have faced challenges from both the pandemic and climatic issues (PricewaterhouseCoopers, 2020). In this context, abiding by an ecological ethic when developing new business ventures that would incorporate cleaner energy and manufacturing systems and mitigate the human health impact of environmentally mediated diseases and pollution becomes crucial. Agricultural production for food security, improved access to water supplies, more benign trajectories of rapid urbanization, effective use of environmental and natural resources to help poverty alleviation, and the growth of existing productive sectors will require support. New and high-value blue economy industries capitalizing on the ocean and aquatic resources as a new economic frontier would need to be ethically explored (PricewaterhouseCoopers, 2020). Each of these topics should be integrated into Business and Management Studies curricula. 
Appropriate teaching and learning approaches to sustainability are also necessary for devising practical protections for the earth's life-support systems (Brunnquell \& Brunstein, 2018; Collins \& Kearins, 2007; Ehrenfeld, 2019). This entails vital discussions on mitigating pressures on the global climate, conserving ecosystems, and protecting biodiversity (Banerjee, 2012). These unparalleled and complex demands of our time call for innovation and entrepreneurship in leading transformative change.

\section{A "Sustainability Mindset"}

Interpretations and contextualization of sustainability play a crucial role in changing attitudes towards it, and a functionalist, or narrow understanding of sustainability leads to limited or superficial action (Banerjee \& Bonnefous, 2011; Ehrenfeld, 2008, 2012, 2019; Gladwin et al., 1995; Milne et al., 2015). The world we inhabit is shaped by the workings of both the "laws of nature and by the networks of rules that constitute human institutions" (Ehrenfeld, 2019, p. 3) so that embedding a community/social and ecological ethic in ensuring economic success is critical. In this regard, adopting a teaching and learning approach to sustainability that switches from the triple bottom line (TBL) which is commonly known as the integration of the 3 P's - people, profit, and planet, to a quadruple bottom line (QBL) approach with the inclusion of "purpose" (4 P's - people, profit, planet, and purpose) would assist students in viewing a business in a broader sense. Such an attitudinal change would also enable decision-makers realize the interconnectedness of all stakeholders, so that they also find meaning in their actions.

Introducing spirituality into sustainability education will also usher in a broader and more organic perspective on sustainability than a materialistic and mechanistic approach (Ehrenfeld, 2012; 2019). Meditation is a mind-based practice which enables self-awareness, and meditation programs could foster a deeper understanding of the interconnectedness of all beings including nature. Training is required to contemplate and act more empathetically and compassionately towards all internal and external stakeholders. "Doing well by doing good" which is a stance that true sustainability leaders live by, needs to be instilled in the minds of Business Studies students whether at undergraduate or postgraduate levels.

Although concerns on sustainability were identified as early as the 1970 s, it was only when several intergovernmental and non-governmental organizations initiated discussions and disseminated statements on sustainable development that the theme of sustainability itself gained prominence and was taken up for research and teaching at academic institutions (Thomas et al., 1999). With the Agenda 2030 on Sustainable Development Goals (SDGs) and the Paris Climate Agreement, a move to mainstream education for sustainable development (ESD) into higher education was initiated under a global action plan in 2015 (Kakuchi, 2014). These initiatives emphasize an ESD that goes beyond the boundaries of specific disciplines.

Kolb and Kolb (2009) also state that knowledge attained in management education needs to filter through to multiple levels, including individual, team, and organization. They underscore that management programs should enhance individual learning in order to promote team and organizational learning. This multi-level approach should, therefore, be 
emphasized in teaching sustainability. Moreover, curriculum revision at higher education level alone will be insufficient.

They are also required at elementary/primary and secondary school levels. A wellintegrated educational approach will inculcate a sense of social responsibility towards sustainability. A study (Abeydeera et al., 2016) conducted with a group of Sri Lankan sustainability managers illustrated that their passion for sustainability in a corporate setting had emerged from their childhood experiences and memories of "being close to nature" including growing up in a village, helping their parents in farming, playing with their friends in the woods etc. (Abeydeera et al., 2016). Thus, a backward integration approach where university education is aligned with school education is essential.

At the same time, higher education needs to be better integrated with industry and business in a forward integration approach. Linking university curricula with industry will ensure better compatibility of students with the requirements of the market/employers and give them credibility (Weligamage, 2009). Postgraduate students will also be able to share and translate their learning experiences with their corporate counterparts and perform as change agents and thought leaders in their respective capacities. Collaborations with other universities and intergovernmental and non-governmental organizations horizontally would also be value additions. A diagrammatic presentation of the multi-level approach indicating backward and forward integration of HEIs is depicted in Figure 1 given below.

Figure 1: A Multilevel Approach to Teaching and Learning Sustainability in Higher Education

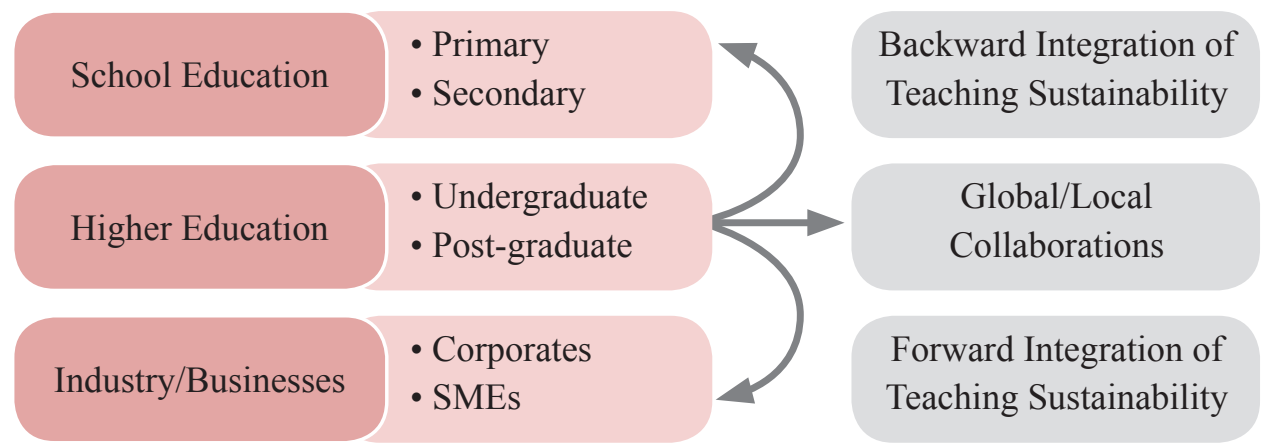

\section{Conclusion}

The COVID-19 pandemic has served as a call to educators to spearhead the transformative role higher education can play towards sustainable development, and to recognize the essential role and responsibility of higher education institutions towards creating sustainable societies. A true transformation - a holistic change that alters the way a business operates - is what is required in today's uncertain climate. It is the only path to creating sustainable societies which will elevate financial performance, build capabilities, and change the culture in ways that will not only get businesses/companies through this global health crisis, but also sustain them in the years to come.

This article underscored the urgent need for educators and students alike to revisit and reconceptualize what sustainability is, and adopt a broader systems perspective 
rather than a narrow functionalist/utilitarian view. An expanded view of sustainability will enable educators to adopt more problem-based, experiential, reflective, critical, and radical teaching and learning approaches rather than staying within mundane, static, and prescriptive modes of teaching. Academics involved in teaching and learning sustainability will need to understand that more fundamental changes to businesses will be needed if they are to do well in the new normal. Emphasizing the integration of business with community, society and nature, and values such as diversity, equity, and inclusion rather than only on business growth, will be an essential act in such a transformation.

Educational administrators also need to rethink how universities, which are often considered drivers for professional managers, address sustainability education. They will not only be required to offer courses that address the job skills which employers seek in the face of the pandemic and beyond, but also ensure that the learning objectives of their HEIs develop high-order, adaptive skills among students. Agility in action with proper and conducive collaborations with relevant stakeholders (e.g., other universities, and intergovernmental and non-governmental bodies) is also of paramount importance.

At the same time, students, as learning partners, must change their attitudes to view businesses not as a part of the problem but as a solution. This calls for a transformative change in learning what sustainability actually is, and an engagement with active, experiential and reflective learning. Finally, future research calls for more empirical studies on sustainability education, and the adoption of interdisciplinary, problem-based, hands-on teaching and learning pedagogical approaches.

\section{References}

Abeydeera, S., Kearins, K., \& Tregidga, H. (2016). Does Buddhism enable a different sustainability ethic at work? Journal of Corporate Citizenship, 62, 109-130.

https://www.jstor.org/stable/90003767

Banerjee, S. B. (2003). Who sustains whose development? Sustainable development and the reinvention of nature. Organization Studies, 24(1), 143-180. https://doi.org/10.1177/0170840603024001341

Banerjee, S. B. (2011). Embedding sustainability across the organization: A critical perspective. Academy of Management Learning \& Education, 10(4), 719-731.

https://www.jstor.org/stable/23100442

Banerjee, S. B. (2012). Critical perspectives on business and the natural environment. In P. Bansal \& A. J. Hoffman (Eds.), The Oxford handbook of business and the natural environment (pp. 572590). Oxford University Press. http://dx.doi.org/10.1093/oxfordhb/9780199584451.003.0031

Banerjee, S. B., \& Bonnefous, A. (2011). Stakeholder management and sustainability strategies in the French nuclear industry. Business Strategy and the Environment, 20, 124-140.

https://doi.org/10.1002/bse.681 
Bawden, R., \& Wals, A. E. J. (2000). Conceptualizing sustainability in education for agriculture and rural development. Polish Journal of Environmental Studies, 9(2), 13-20.

Bennett, N., \& Lemoine, J. G. (2014). What a difference a word makes: Understanding threats to performance in a VUCA world. Retrieved on November 13, 2020 from https://www.researchgate.net/publication/260313997_What_a_difference_a_word_makes_ Understanding_threats_to_performance_in_a_VUCA_world

Biggs, J. (1999). What the student does: Teaching for enhanced learning. Higher Education Research \& Development, 18(1), 57-75.

Brundiers, K., \& Wiek, A. (2013). Do we teach what we preach? An international comparison of problem- and project-based learning courses in sustainability. Sustainability, 5(4), 1725-1746. https://doi.org/10.3390/su5041725

Brundiers, K., Wiek, A., \& Redman, C. L. (2010). Real-world learning opportunities in sustainability: from classroom into the real world. International Journal of Sustainability in High Education, 11(4), 308-324. https://doi.org/10.1108/14676371011077540

Brunnquell, C., \& Brunstein, J. (2018). Sustainability in management education: Contributions from critical reflection and transformative learning. Metropolitan Universities, 29(3), 25-42.

https://doi.org/10.18060/21466

Buttermore, J. A. (2011). The team-taught cross-functional core: Insights from a long-term undergraduate program. Journal of Education for Business, 86(4), 240-247.

https://doi.org/10.1080/08832323.2010.498843

Clark, W. C. (2007). Sustainability science: a room of its own. Proceedings of the National Academy of Sciences, 104(6), 1737-1738. https://doi.org/10.1073/pnas.0611291104

Cohen, D., Furstenthal, L., \& Jansen, L. (2020, November 12). Healthcare innovation: Building on gains made through the crisis. McKinsey.

https://www.mckinsey.com/industries/pharmaceuticals-and-medical-products/our-insights/ healthcare-innovation-building-on-gains-made-through-the-crisis

Collins, E., \& Kearins, K. (2007). Exposing students to the potential and risks of stakeholder engagement when teaching sustainability: A classroom exercise. Journal of Management Education, 31(4), 521-540. https://doi.org/10.1177/1052562906291307

Daniels, P. L. (1998). Economic change, the environment and Buddhism in Asia. International Journal of Social Economics, 25(6/7/8), 968-1004. https://doi.org/10.1108/03068299810212405

Daniels, P. L. (2007). Buddhism and the transformation to sustainable economies. Society and Economy, 29(2), 155-180. https://doi.org/10.1556/socec.29.2007.2.3

Daniels, P. L. (2011). Buddhism and sustainable consumption. In L. Zsolnai (Ed.), Ethical principles and economic transformation: A Buddhist approach (pp. 35-60). Springer.

https://doi.org/10.1007/978-90-481-9310-3_3 
Daniels, P. L. (2014). Practical wisdom for managing sustainable enterprises - synthesizing Buddhism and ecological economics. Journal of Management Development, 33(8/9), 797-811. http://dx.doi.org/10.1108/JMD-09-2013-0121

Ehrenfeld, J. R. (2008). Sustainability by design: A subversive strategy for transforming our consumer culture. Yale University Press.

Ehrenfeld, J. R. (2012). Beyond the brave new world: Business for sustainability. In P. Bansal \& A. J. Hoffman (Eds.), The Oxford handbook of business and the natural environment (pp. 611-619). Oxford University Press. http://dx.doi.org/10.1093/oxfordhb/9780199584451.003.0033

Ehrenfeld, J. R. (2019). The right way to flourish: Reconnecting to the real world. Taylor \& Francis.

Ehrenfeld, J. R., \& Hoffman, A. J. (2013). Flourishing: A frank conversation about sustainability. Stanford University Press.

Elkington, J. (1997). Cannibals with forks. Triple bottom line of 21st century business. Capstone Publishing.

Fernando, M., \& Almeida, S. (2012). The organizational virtuousness of strategic corporate social responsibility: A case study of the Sri Lankan family-owned enterprise MAS Holdings. European Management Journal, 30(6), 564-576. https://doi.org/10.1016/j.emj.2012.08.003

Fernando, M., \& Jackson, B. (2006). The influence of religion-based workplace spirituality on business leaders' decision-making: An interfaith study. Journal of Management \& Organization, 12(1), 23-39. http://dx.doi.org/10.5172/jmo.2006.12.1.23

Fernando, M., Fox, S., Bandara, R., \& Hartley, D. (2020). Lowering the walls: an integrative approach to first-year undergraduate business education. Journal of International Education in Business, 13(2), 275-295. https://doi.org/10.1108/JIEB-04-2020-0027

Fernando, S., Lawrence, S., Kelly, M., \& Arunachalam, M. (2015). CSR practices in Sri Lanka: An exploratory analysis. Social Responsibility Journal, 11(4), 868-892. http://dx.doi.org/10.1108/SRJ-08-2013-0101

Fogarty, F., Villamagna, A., Whitley, A., \& Pippins, K. (2013). The capacity to endure: Following nature's lead. Sustainability, 5, 2480-2494. http://dx.doi.org/10.3390/su5062480

Gladwin, T. N., Kennelly, J. J., \& Krause, T. (1995). Shifting paradigms for sustainable development: Implications for management theory and research. Academy of Management Review, 20(4), 874907. https://doi.org/10.2307/258959

Globescan. (2020). The European pact for sustainable industry: Making the green deal a success (CSR Europe white paper 2020). CSR Europe.

Gombrich, R., \& Obeyesekere, G. (1988). Buddhism transformed: Religious change in Sri Lanka. Princeton University Press.

Hahn, T., Figge, F., Pinkse, J., \& Preuss, L. (2010). Trade-offs in corporate sustainability: You can't have your cake and eat it. Business Strategy and the Environment, 19, 217-229.

https://doi.org/10.1002/bse.674 
Harris, C., \& Tregidga, H. (2012). HR managers and environmental sustainability: Strategic leaders or passive observers? International Journal of Human Resource Management, 23(2), 236-254. http://dx.doi.org/10.1080/09585192.2011.561221

Higher Education for Sustainable Development. (2015). Nagoya Declaration on Sustainability in Higher Education. United Nations. Retrieved November 21, 2020, from https://sustainabledevelopment.un.org/content/documents/5864Declaration\%20-\%20 Higher\%20Education\%20for\%20Sustainable\%20Development\%20Nagoya\%202014.pdf

Jones, P., Selby, D., \& Sterling, S. (2010). Sustainability education: Perspectives and practice across higher education. Earthscan.

Kakuchi, S. (2014). Declaration on higher education for sustainability. Retrieved November 19, 2020 from https://www.universityworldnews.com/post.php?story=20141128111121646

Karunatilake, H. N. S. (2004). Banking sector reforms. In D. Keown (Ed.), Buddhist studies from India to America (pp. 218-226). Sage Publications.

Kearins, K., \& Springett, D. (2003). Educating for sustainability: Developing critical skills. Journal of Management Education, 27(2), 188-204. https://doi.org/10.1177\%2F1052562903251411

Kearins, K., Collins, E., \& Tregidga, H. (2010). Beyond corporate environmental management to a consideration of nature in visionary small enterprise. Business and Society, 49(3), 512-547. https://doi.org/10.1177/0007650310368988

Kolb, A. Y., \& Kolb, D. A. (2009). Experiential learning theory: A dynamic, holistic approach to management learning, education and development. The SAGE handbook of management learning, education and development (pp. 42-68). Sage. http://dx.doi.org/10.4135/9780857021038.n3

Kumarasinghe, S., \& Hoshino, Y. (2010). The role and perceptions of middle managers and their influence on business performance: The case of Sri Lanka. International Business Research, 3(4), 3-16. https://doi.org/10.5539/ibr.v3n4p3

Laszlo, C., Brown, J. S., Ehrenfeld, J. R., Gorham, M., Pose, I. B., Robson, L., Saillant, R., Sherman, D., \& Werder, P. (2014). Flourishing enterprise: The new spirit of business. Stanford University Press.

Lattuca, L. R., Voigt, L. J., \& Fath, K. Q. (2004). Does interdisciplinarity promote learning? Theoretical support and researchable questions. The Review of Higher Education, 28(1), 23-48. http://dx.doi.org/10.1353/rhe.2004.0028

Lindvig, K., \& Ulriksen, L. (2019). Different, difficult, and local: A review of interdisciplinary teaching activities. The Review of Higher Education 43(2), 697-725.

https://doi.org/10.1353/rhe.2019.0115

Martens, P., Covers, R., \& Roorda, N. (2010). Sustainability, science and higher education: the need for new paradigms. Sustainability: The Journal of Record, 3(5), 294-303, https://doi.org/10.1089/SUS.2010.9744 
Milne, J. M., Kearins, K., \& Walton, S. (2006). Creating adventures in wonderland: The journey metaphor and environmental sustainability. Organization, 13(6), 801-839.

https://doi.org/10.1177/1350508406068506

Molthan-Hill, P. (2015). Making the business case? Intercultural differences in framing economic rationality related to environmental issues. Critical Perspectives on International Business, 11(1), 72-91. https://doi.org/10.1108/cpoib-07-2012-0033

Nanayakkara, G. (1992). Culture and management in Sri Lanka. Postgraduate Institute of Management.

Nanayakkara, G. (1997). Some reflections of Buddhism on morality in business and management. Sri Lankan Journal of Management, 2(3), 217-232.

O’Byrne, D., Dripps, W. \& Nicholas, K. A. (2015). Teaching and learning sustainability: An assessment of the curriculum content and structure of sustainability degree programs in higher education. Sustainability Science, 10, 43-59. https://doi.org/10.1007/s11625-014-0251-y

O'Connell, T. S., \& Dyment, J. E. (2011). The case of reflective journals: is the jury still out? Reflective Practice,12(1), 47-59. http://dx.doi.org/10.1080/14623943.2011.541093

PricewaterhouseCoopers. (2020). COVID-19 outbreak: Impact on Sri Lanka and recommendations. Sri Lanka.

Roome, N. (2012). Looking back, thinking forward: Distinguishing between weak and strong sustainability. In A. J. Hoffman \& P. Bansal (Eds.), The Oxford handbook of business and the natural environment (pp. 620-629). Oxford University Press.

https://doi.org/10.1093/oxfordhb/9780199584451.003.0034

Schein, S. (2015). A new psychology for sustainability leadership: The hidden power of ecological worldviews. Greenleaf.

Shay, S. (2016). Curricula at the boundaries. Higher Education, 71, 767-779.

https://doi.org/10.1007/s10734-015-9917-3

Snyder, H. (2019). Literature review as a research methodology: An overview and guidelines. Journal of Business Research, 104, 333-339. https://doi.org/10.1007/s10734-015-9917-3s

Springett, D. (2003). Business conceptions of sustainable development: A perspective from critical theory. Business Strategy and the Environment, 12, 71-86. https://doi.org/10.1002/bse.353

Thomas, I., Kyle, I., \& Alvarez, A. (1999). Environmental education across the curriculum: A process. Environmental Education Research, 15/16, 95-101.

United Nations Educational, Scientific and Cultural Organization. (2020). Fiscal response to education and training in the context of COVID-19. Paris, France.

Wals, A. E. J, \& Jicklin, B. (2002). "Sustainability" in higher education: From doublethink and newspeak to critical thinking and meaningful learning. International Journal of Sustainability in Higher Education, 3(3), 221-232. http://dx.doi.org/10.1108/14676370210434688 
Weligamage, S. S. (2009). Graduates' employability skills: Evidence from literature review. University of Kelaniya.

Yarime, M., Trencher, G., Mino, T., Scholz, R. W., Olsson, L., Ness, B., Frantzeskaki, N., \& Rotmans, J. (2012). Establishing sustainability science in higher education institutions: towards an integration of academic development, institutionalization, and stakeholder collaborations. Sustainability Science, 7(1), 101-113. https://doi.org/10.1007/s11625-012-0157-5 